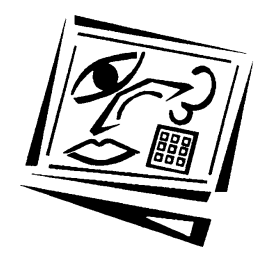

Australasian Journal of Educational Technology

Volume 26, Number 6, 2010

ISSN 1449-5554 (online)

\title{
Contents
}

Editorial 26(6)

iii-viii

Web-based lecture technologies: Highlighting the changing nature of

teaching and learning

Greg Preston, Rob Phillips, Maree Gosper, Margot McNeill,

Karen Woo and David Green

Blended learning environments: Using social networking sites to enhance

the first year experience Joshua McCarthy

Secondary school socio-cultural context influencing ICT integration:

A case study approach

Shanti Divaharan and Lim Cher Ping

Measuring learner's performance in e-learning recommender systems

Khairil Imran Ghauth and Nor Aniza Abdullah

Using contemporary topics and Internet resources to stimulate

student-centred learning Susan E. Lee and Kyra J. Woods

Radical transparency: Open access as a key concept in wiki pedagogy 791-809 Rolf K. Baltzersen

Learning to play games or playing games to learn? A health education case study with Soweto teenagers

Alan Amory

Online collaboration and offline interaction between students using

asynchronous tools in blended learning

Mei-jung Wang

Off campus students' experiences collaborating online, using wikis Debbi Weaver, Shane Viper, Jennifer Latter and P. Craig McIntosh

Internet tools for language learning: University students taking control

of their writing

Mark A. Conroy

$861-882$

Blended learning using video-based blogs: Public speaking for English as a second language students

$\mathrm{Ru}$-Chu Shih

Adoption of blogging by a Chinese language composition class in a

vocational high school in Taiwan

$898-916$

Shi-Jer Lou, Shi-Chiao Wu, Ru-Chu Shih and Kuo-Hung Tseng 
The Australasian Journal of Educational Technology (AJET) is a refereed research journal published 6 times per year by the Australasian Society for Computers in Learning in Tertiary Education (ascilite). AJET retired its printed version (ISSN 1449-3098) at the end of Volume 23, 2007, and from Volume 24, 2008, the journal is open access, online only (ISSN 1449-5554), and does not have paid subscriptions.

(C) 2010 Authors retain copyright in their individual articles, whilst copyright in AJET as a compilation is retained by the publisher. Except for authors reproducing their own articles, no part of this journal may be reprinted or reproduced without permission. For further details, and for details on submission of manuscripts and open access to all issues of AJET published since the journal's foundation in 1985, please see http:/ / www.ascilite.org.au / ajet/

For editorial inquiries, contact the Editor, Associate Professor Catherine McLoughlin, School of Education (ACT), Australian Catholic University, PO Box 256, Dickson ACT 2602, Australia. Email: Catherine.McLoughlin@acu.edu.au, Tel: +61262091100 Fax +61262091185.

For review process, production, website and business matters, contact the Production Editor, Dr Roger Atkinson, 5/ 202 Coode Street, Como WA 6152, Australia. Email: rjatkinson@bigpond.com, Tel: +61 89367 1133. Desktop publishing (PDF versions) and HTML by Roger Atkinson.

AJET is managed by a Committee comprising ASCILITE Executive nominees, the convenors or nominees from previous ascilite Conferences, and AJET's previous editors and current senior editorial staff. The 2009 Management Committee members are:

Professor Mike Keppell, Charles Sturt University, ASCILITE President

Dr Philippa Gerbic, Auckland University of Technology, ASCILITE Executive

Professor Geoffrey Crisp, University of Adelaide, ASCILITE 2003 Convenor

Dr Rob Phillips, Murdoch University, ASCILITE 2004 Convenor

Professor Peter Goodyear, University of Sydney, ASCILITE 2006 Convenor

Dr Dale Holt, Deakin University, ASCILITE 2008 Convenor

Professor Ron Oliver, Edith Cowan University, AJET Editor 1997-2001

Assoc Prof Catherine McLoughlin (Editor), Australian Catholic University

Dr Roger Atkinson (Production Editor)

AJET's Editorial Board (see http://www.ascilite.org.au/ajet/about/editorialboard.html) reflects the journal's commitment to academic excellence in educational technology and related areas of research and professional practice, our vision of an international journal with an Australasian regional emphasis, and our origins as a professional and learned society publication. 


\section{Editorial 26(6)}

\section{A Letter to the Editor: Defending the ERA initiative}

\section{Roger Atkinson}

This Editorial contains another first for AJET: the publication of the journal's first "Letter to the Editor". The letter is from (or over the signature of) Senator the Hon Kim Carr, Minister for Innovation, Industry, Science and Research (although there is another name, "Eric", appearing at the end of the document), dated 14 July 2010. The letter arrived as hard copy, so the text below was obtained by scanning and OCR (optical character recognition). The origin of the correspondence has been detailed in AJET Editorial 26(5), topic “Community Cabinet Meeting, Como Secondary College, 9 June 2010" [1].

\section{Dear Dr Atkinson}

I understand that you met with the Special Minister of State, Senator the Hon Joe Ludwig, at the Perth community cabinet meeting on 9 June 2010 and tabled a paper requesting that I obtain advice from the Australian Research Council (ARC) regarding matters relating to the Excellence in Research (ERA) 2010 initiative. I have since sought clarification from the ARC and wish to provide you with this information.

I would like to begin by providing some background information about the ERA initiative. ERA aims to identify and promote excellence across the full spectrum of research activity in Australia's higher education institutions. ERA reflects the Government's commitment to a transparent, streamlined approach to the evaluation of the quality of research undertaken in Australia's universities.

The ERA initiative will use a range of indicators and other proxies to support the evaluation of research excellence. Research Evaluation Committees (RECs), comprising experienced, internationally-recognised experts, will evaluate the overall research performance of disciplines within institutions. These evaluations will be informed by a range of indicators. Ranked outlets form one of the indicators of research quality, along with citation analysis, peer review, and peer-reviewed Australian and international research income.

The ERA 2010 Ranked Journal List was developed over a period of two years through several rounds of sector consultation with the public, Australian discipline peak bodies, and individual discipline experts from Australia and overseas. The final list reflects feedback received throughout the review process. In many cases, journal ranks changed from the early draft lists released for public consultation in 2008, after the ARC considered recommendations from relevant peak bodies and discipline experts about the appropriate quality tier.

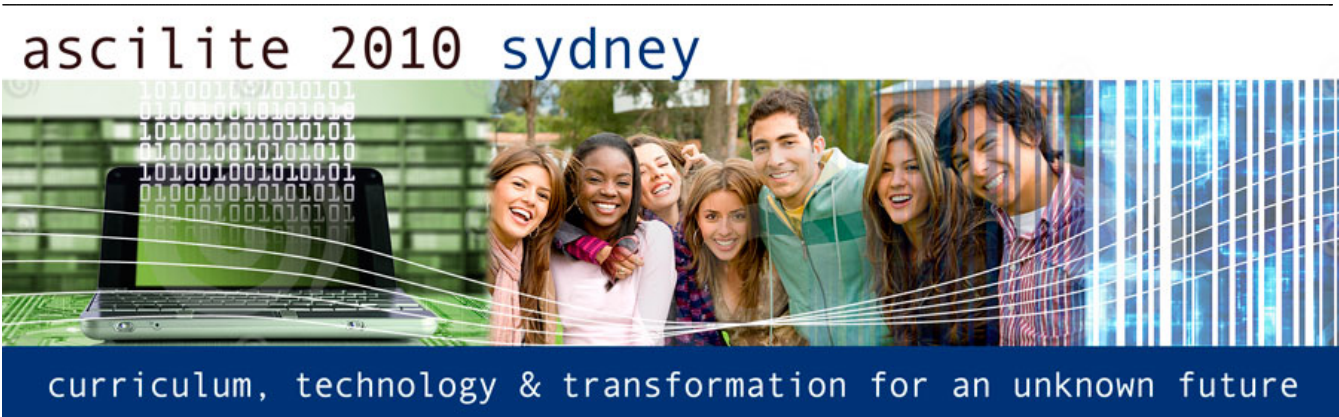

Sydney, 5-8 December 2010. Website http://www.ascilite.org.au/conferences/sydney10/ 


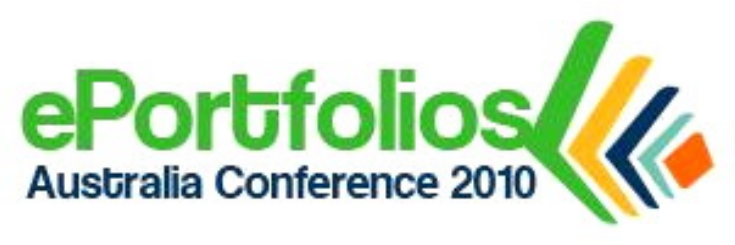

\author{
ePortfolios Australia \\ Conference 2010.
}

Melbourne, 3-4 November

http://www.flexiblelearning.net.au/ content/e-portfolios-australia

You requested that the ARC provide a research paper about the way ERA journal quality tiers were developed. The ARC has provided the following information, and more detailed information can be found in the documents referred to below.

The ERA journal quality tier criteria were developed by Linda Butler, a world recognised bibliometrician and head of the Research Evaluation and Policy Project at the Australian National University. The criteria were refined with feedback from the ERA Indicators Development Group (IDG), the Australian Learned Academies and other Australian discipline peak bodies and societies.

To develop indicators for the ERA initiative, the ARC was assisted by expert advice provided by the IDG, and consultation with the research and higher education sector. The IDG comprised a core of research metrics and statistical experts, with the involvement of particular discipline experts as required. The IDG provided its recommendations to Professor Margaret Sheil in early December 2008. The ARC developed two key documents on the basis of IDG recommendations:

- The ERA Indicator Principles, which provide the overall context and application of the indicator approach.

- The ERA Indicator Descriptors, which provide the detail of each indicator type, and an example profile of how they would be presented to RECs to inform ERA evaluations. [Footnote: These documents can be accessed from the ARC website at: http: / / arc.gov.au/era/key_docs09.htm]

In addition, the ERA journal quality tier criteria were tested through the two-year consultation process to develop and review the Ranked Journal List; the 2009 ERA trial; and the 2009 public consultation on ERA indicators.

You have asked for an academic-standard exposition of the methodology. You will be pleased to know that there is a very broad base of literature supporting research quality assessment, the use of citation analysis in place of peer review, and use of journal ranking metrics, and I commend to you the various publications in the area. Some of the key authors include Charles Oppenheim, Jonathan Adams, Linda Butler, Paul Bourke, Anne-Wil Harzing, Wolfgang Glaenzel, Henk Moed and Anthony van Raan. In addition, the Higher Education Funding Council for England (HEFCE) has commissioned a number of informative reports looking at various aspects of research quality assessment. Both Elsevier and Thomson Reuters have also produced documents outlining their approaches to journal ratings, such as the Journal Impact Factor.

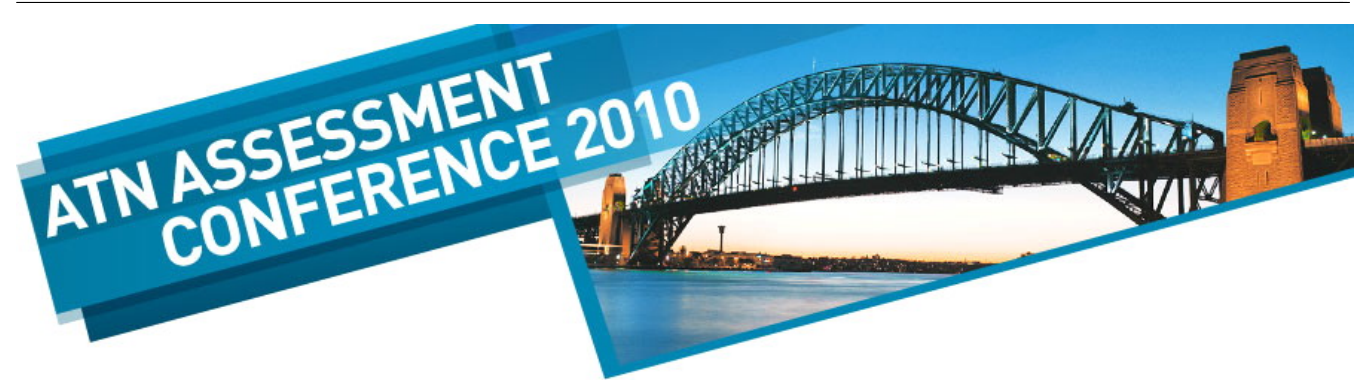

ATN Assessment 2010 Conference: Sustainability, Diversity and Innovation, 18-19 November 2010, University of Technology Sydney. http://www.iml.uts.edu.au/atnassessment/ 


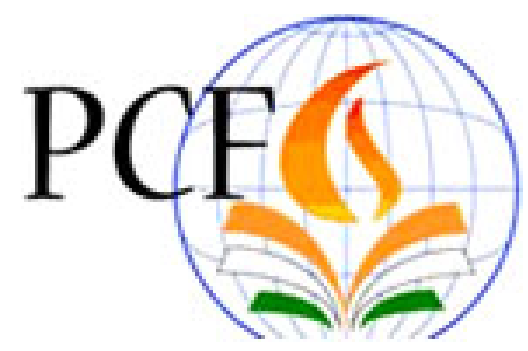

\section{Sixth Pan-Commonwealth \\ Forum on Open Learning}

\section{4-28 November 2010, Kochi, India} http://www.pcf6.net/

Commonwealth of Learning and Indira Ghandi National Open University

\begin{abstract}
You also requested a review of the impact of the ERA ranked outlets on Australian based journals. At this stage it is too soon to predict the impact of ERA ranked outlets upon journals and conferences. In developing the ERA 2010 Ranked Journal List and Ranked Conference List, the ARC did not collect information about the place of publication of journals or conference proceedings. This is because the criteria are based on the overall quality of each journal or conference, and ERA is designed to allow for international comparisons of Australia's research quality.
\end{abstract}

The journal quality criteria were developed to reflect the overall quality of the journal rather than their relevance to particular disciplines or countries. The tier definitions do not include a 'regional relevance' factor, unlike some overseas rankings such as the European Science Foundation (ESF) humanities journal rankings. A national relevance factor is not appropriate for ERA, because ERA is intended to allow for comparisons of Australia's research both nationally and internationally.

Thank you for taking the time to put forward your views on ERA. I have provided a copy of your paper to Professor Margaret Sheil, Chief Executive Officer of the ARC. Professor Sheil and the ERA team welcome comments and feedback on ERA. Should you wish to provide further feedback, you are welcome to contact the ARC via email at era@arc.gov.au or via telephone (02) 62876755.

Yours sincerely

Kim Carr

Eric

PO Box 6022, Parliament House, Canberra ACT 2600

Well, there we have the ARC's outline of how it used research to inform and develop the "Tiers for the Australian Ranking of Journals"! It seems clear that the ARC will not or perhaps cannot give any detailed account of the method underlying its considerations of "... recommendations from relevant peak bodies and discipline experts about the appropriate quality tier." The ARC's description of method will not extend any further than brief phrases such as "Learned Academies and discipline peak bodies involved in developing and reviewing the Journal List are listed here..."

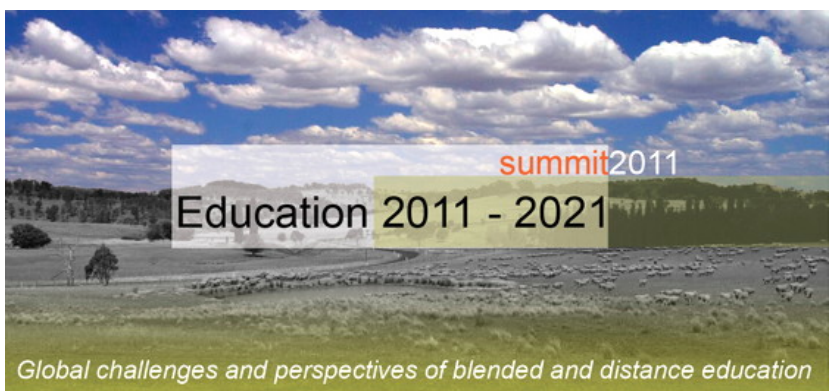

\title{
Education 2011 to 2021 -
} Summit 2011

Sydney, 14-18 February 2011

http://www.dehub.edu.au/summit2011/

DE Hub and ODLAA 


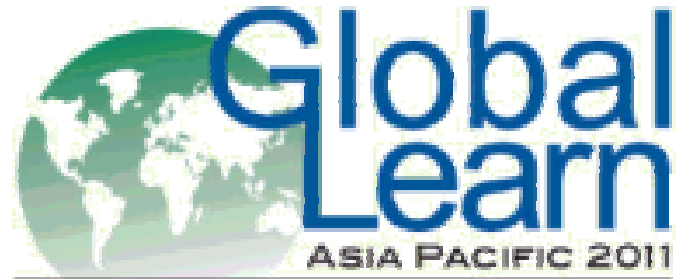

Chobd Canterence on Learning and Technology
Association for the Advancement of Computing in Education (AACE)

Melbourne, 28 March - 1 April 2011

Submissions close 25 Oct 2010

http://aace.org/conf/glearn/

[2] and "...the consolidated draft Ranked Journal List was provided to over 700 expert reviewers who assisted the ARC in developing the ERA 2010 journal list to allow for a final check of ranks ..."[3]. There is no mention of the instructions that were given to the "expert reviewers", their identities and how they were selected (i.e. proper characterisation of the population that was sampled), or the extent of interreviewer differences and how these were resolved (experienced reviewers for educational journals may find these phrases familiar; deficiencies in method or reporting of method is a frequently occurring reason for recommending rejection of a submission). In some cases, diligent searching may reveal names of reviewers, for example the Australian Council of Engineering Deans list [4], or a few details about the process that was followed, for example by the Australian Psychological Society [5], but in general there seems to be very little public information.

Some mischievous observers may be tempted to note that the term "peak bodies" has a rhyming association with "clique bodies". My trusty old Macquarie 3rd Ed records:

clique noun 1. a small set or coterie, especially one that is snobbishly exclusive

pique verb $(t) \mathbf{1}$. to affect with sharp irritation, especially by some wound to pride [6]

The ARC's letter does imply that it has developed a "Tiers" methodology upon a "very broad base of literature", thereby generating an opportunity for researchers to examine the extent to which "Tiers" is consistent with that "very broad base of literature". Another key opportunity for researchers is suggested by the ARC's lack of comment about the core of the problem, which I tried to summarise in several sentences quoted in AJET Editorial 26(5):

[Perhaps we can] ... move towards more meaningful, better researched, more evidence based, sounder explanations of the "Tiers", and some improved recognition of the role of journals and their editors. More meaningful than the PowerPoints listed under http:/ / www.arc.gov.au/media/ARC_Presentations.htm. After all, we editors are the coal face persons who, by means of the peer review processes that we organise, provide the ARC with one metric, albeit a crude metric, for assessing research excellence. Editors are the persons who perhaps are better placed than others to be sources of evidence on the goodness of correlations between "tier rank of research outlet", "esteem" as estimated by citation counts, or various other metrics, and the merit of the research that is recorded in a publication in a "ranked outlet". [1]

\section{$\square$ CCA-EDUCAUSE \\ AUSTRALASIA 2011}

THE GAME HAS CHANGED

\section{CAUDIT CAUL ACODE}

The game has changed

Sydney, 3-6 April 2011

http://ccaeducause.caudit.edu.au/ index.php/educause/ccae2011 
Put in another way, how can we research assertions of the form, "Professor A's educational technology research was published in C\&E (or other Tier A journals BJET, or JCAL, or ALT-J) and therefore it is better than Ms B's research that was published in AJET (or in other Tier B journals - ET\&S, JTaTE, etc) [7], and thus Professor A will get more research funding than Ms B"? To which the ARC will reassert that the "... ERA is designed to allow for international comparisons of Australia's research quality" and that it is pursuing "... the overall research performance of disciplines within institutions" (i.e. not individual researchers); to which critics may respond, "Will the ARC fund some research into rank and file researcher perceptions about the impact of the ERA process, to test these contrasting assertions and others?"

Yet another opportunity for relevant research arises from the new importance accorded to the role of the "... peer review processes that we organise, [which] provide the ARC with one metric, albeit a crude metric, for assessing research excellence." [1] We are very well aware that quite often a review process leads to large differences between reviewers. The process can be quite subjective and sometimes idiosyncratic. From time to time we look up David Pannell's incredibly pertinent poem, I'm the referee [8] (though the overwhelming majority of AJET's reviewers a re far, far better than the 'total bastard' portrayed in David's poem). The research that we need is into communicating an improved understanding about peer review. It is not a precise, fully objective process; it is variable, and we need to see more publication of statistics concerning matters such as inter-reviewer differences, rejection rates, and the extent to which authors "shop around" and the submission sequences that they may follow. The latter is not an easy topic, for example I have on file records about a paper which after an "editorial reject" from AJET was submitted unchanged to [name of a higher ranked journal deleted] and published.

Research into the impact of the ERA seems to be developing quite rapidly into a rich field encompassing many perspectives, including the differential impact upon open access publications (Mercieca \& Macauley, 2008 [9]), changes in the publishing behaviour of Australian academics (Lamp, 2009 [10]), 'alternative' journal impact measures for the ranking of Australian social sciences and humanities journals (Genoni, Haddow \& Dumbell, 2009[11]), and the risks of ERA-imposed fragmentations of disciplines into sub-disciplines (Graham, 2008[12]).

Clearly, there is much work to do, but it may be spiced and spurred by the prospect that research into the ERA process may establish that the ARC has attained something less than an impeccable or $\mathrm{A}^{*} / \mathrm{A}$ use of research to inform its formulations of policies. To illustrate that the subjects are not happy, consider the tart response put to the ARC by the President of the Society of Australian Systematic Biologists: 
From: Bob Mesibov<mesibov@southcom.com.au>

To: margaret.sheil@arc.gov.au

Subject: ERA ranking of systematics journals - further SASB comment

Date: Fri, 19 Mar 2010 22:22:02 +1100

Dear Professor Sheil,

Thank you for your posted reply. You have explained how the List was produced and why you might be satisfied with it: expert advice was used. You have also left the door open for a future revision, date unspecified.

You have not, however, specifically addressed the concerns of systematists or the special nature of taxonomic publication. Instead, you have given me even more reason to distrust the process by which the List was generated.... [see 13. for full text]

Roger Atkinson and Catherine McLoughlin AJET Production Editor and AJET Editor

\section{Endnotes}

1. AJET Editorial 26(5). Community Cabinet Meeting, Como Secondary College, 9 June 2010. http:/ / www.ascilite.org.au/ajet/ajet26/editorial26-5.html

2. ARC (undated). Learned Academies and Discipline Peak Bodies involved in developing and reviewing the ERA 2010 Ranked Journal List. http: / / www.arc.gov.au/pdf/ERA expert reviewers.pdf

3. ARC (2010). Quotations are from 'Ranked Journal List Development'. http: / / www.arc.gov.au/era/journal_list_dev.htm

4. ERA Ranked Lists of Journal and Conference Publications for Engineering [viewed 20 Oct 2010] http: / / www.ecms.adelaide.edu.au/ERAEngineering/

5. FASTS (Federation of Australian Scientific and Technological Societies) (2010). Issues with the ERA journal ranking. [verified 20 Oct 2010] http:/ / www.amos.org.au/sb/modules/news/ attachments $/ 91 / 1008 \% 20-\% 20 \% 20$ ARC $\% 20$ response $\% 20$ to $\% 20$ issues $\% 20$ raised $\% 20$ by $\% 20$ FASTS $\% 20$ members\%20regarding \%20ERA \%20(for\%20distribution).pdf

6. The Macquarie Dictionary (1997). 3rd ed. Sydney: The Macquarie Library.

7. For acronyms and Tier rankings, see AJET Editorial 26(5). Idle Moment 40: Impact Factor revisited. http: / / www.ascilite.org.au/ ajet / ajet26/ editorial26-5.html

8. Pannell, D. J. (2002). Prose, psychopaths and persistence: Personal perspectives on publishing. Canadian Journal of Agricultural Economics, 50(2), 101-116.

http:/ / www.general.uwa.edu.au/u/dpannell/prose.htm

9. Mercieca, P. \& Macauley, P. (2008). A new era of open access? Australian Academic $\mathcal{E}$ Research Libraries, 39(4), 243-252. [verified 20 Oct 2010; a Tier B journal] http: / / researchbank.rmit.edu.au/ eserv/ rmit:2219/n2006009250.pdf

10. Lamp, J. W. (2009). Journal ranking and the dreams of academics. Online Information Review, 33(4), 827-830. [verified 20 Oct 2010; a Tier B journal] http:/ / lamp.infosys.deakin.edu.au/pubs/09_OIR-era-process.pdf

11. Genoni, P., Haddow, G. \& Dumbell, P. (2009). Assessing the impact of Australian journals in the social sciences and humanities. In Proceedings ALIA Information Online 2009, Sydney, 2022 January. http: / / conferences.alia.org.au/online2009/ docs/PresentationC16.pdf

12. Graham, L. J. (2008). Rank and file: Assessing research quality in Australia. Educational Philosophy and Theory, 40(7). [verified 20 Oct 2010; a Tier $A^{*}$ journal] http:/ / bulletin.edfac. usyd.edu.au/wp-content/uploads / 2008/11/rank-and-file_era-2008_graham-doc.pdf

13. Mesibov, B. (2010). Email from the President, Society of Australian Systematic Biologists, to Professor Margaret Sheil, ERA, 19 March http:/ / www.sasb.org.au/archive/SASB_to_ARC_19-3-2010.pdf

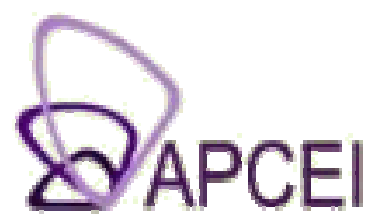

5th Asia Pacific Conference on Educational Integrity

The University of Western Australia

Perth, 26-28 September 2011

http://www.catl.uwa.edu.au/5apcei 